\title{
Correction to: Recent Trends in Immigrant Fertility in Australia
}

\author{
Bernard Baffour $^{1}$ (1) $\cdot$ James Raymer ${ }^{1} \cdot$ Ann Evans $^{1}$ \\ Published online: 21 October 2020 \\ (C) Springer Nature B.V. 2020
}

\section{Correction to: Journal of International Migration and Integration https://doi.org/10.1007/s12134-020-00767-0}

The original version of the article unfortunately contained errors.

The title was incorrect and did not reflect the paper's focus. The correct title is shown above.

The two tables also contained formatting errors.

The original article has been corrected.

Publisher's Note Springer Nature remains neutral with regard to jurisdictional claims in published maps and institutional affiliations.

The online version of the original article can be found at https://doi.org/10.1007/s12134-020-00767-0

Bernard Baffour

bernard.baffour@anu.edu.au

James Raymer

james.raymer@anu.edu.au

Ann Evans

ann.evans@anu.edu.au

1 School of Demography, Australian National University, 9 Fellows Road, Acton, Canberra, Australian Capital Territory 2601, Australia 